\title{
Edge effects on the lichen genus Lobaria in Atlantic Canadian Forests
}

\author{
by Melanie Barry 1,*, Richard Troy McMullin² and Andrew Horn ${ }^{3}$
}

\begin{abstract}
Clear-cut or mosaic forestry practices are known to reduce biodiversity in harvested areas, but the biodiversity in the remaining adjacent forests is also affected. Interior parts of the forest that become edge have increased light, wind, and temperature, and a decrease in moisture. Species with a narrow range of tolerance to environmental change are most affected. To better understand this 'edge effect' in the Acadian Forest, 20 mature deciduous stands in northeastern New Brunswick were examined that were adjacent to clear-cuts ranging from 6-11 years old. We used lichens as our bioindicators and selected the genus Lobaria because it is particularly sensitive to disturbance, but also common in mature deciduous forests of this region. Three Lobaria species that are known to occur in the Acadian Forest were examined: L. pulmonaria, L. quercizans, and L. scrobiculata. Canopy closure, temperature, and presence data were recorded at the forest edge and at the first occurrence of any of these three species along a transect running directly into the forest (three transects at each stand, 60 total). Our results show that the species selected have a negative response to newly created forest edges. Lobaria pulmonaria was the most tolerant to edge effects followed by L. quercizan and L. scrobiculata. The mean occurrence distance from the forest edge for all three species was $12.12 \mathrm{~m}( \pm 5.66)$. Forest managers can use these findings to better understand the impacts of clear-cutting on the biodiversity that inhabits the edges created in the residual forests.
\end{abstract}

Key words: Conservation, sustainable forest management, Acadian Forest, edge effects, fragmentation, biodiversity

\section{RÉSUMÉ}

Cest un fait reconnu que les pratiques forestières comme la coupe à blanc ou de la coupe en mosaïque réduisent la biodiversité dans les zones exploitées, mais aussi dans les étendues boisées adjacentes. Les zones situées à l'intérieur de la forêt qui deviennent les bordures subissent une augmentation de la luminosité, de la vitesse du vent et de la température, ainsi qu'une diminution de l'humidité. Les espèces qui nont qu'une faible tolérance aux perturbations environnementales en sont les plus affectées. Afin de mieux comprendre « l'effet de bordure » dans la forêt acadienne, nous avons étudié 20 peuplements feuillus à maturité du nord-est du Nouveau-Brunswick adjacents à des coupes à blanc datant de 6 à 11 ans. Nous avons choisi d'utiliser les lichens comme bio-indicateurs et particulièrement ceux du genre Lobaria qui savère être particulièrement sensible aux perturbations, mais aussi bien adapté aux forêts feuillues matures de la région. Létude a porté sur trois espèces de Lobaria qui se retrouvent dans la forêt acadienne : L. pulmonaria, L. quercizans et L. scrobiculata. Les observations portaient sur la fermeture du couvert, la température et la présence de ces espèces en bordure de la forêt, ainsi que la première occurrence de n'importe laquelle de ces trois espèces le long d'un transect entrant directement dans la forêt (trois transects dans chaque peuplement, 60 au total). Nos résultats indiquent que les espèces retenues ont réagi négativement à la création récente de bordures forestières. L. pulmonaria s'est avérée être la plus tolérante aux effets de bordure, suivie par L. quercizan et L. scrobiculata. La distance moyenne à partir de la bordure avant de relever la présence d'une des espèces était de $12,12 \mathrm{~m}( \pm 5,66)$. Ces résultats aideront les aménagistes forestiers à mieux comprendre leffet de la coupe à blanc sur la biodiversité au sein des bordures créées dans les forêts résiduelles.

Mots clés : conservation, aménagement forestier durable, forêt acadienne, effet de bordure, fragmentation, biodiversité

\section{Introduction}

New Brunswick's Crown forest ecosystems provide habitat for approximately 30000 species of wildlife, fish, and other organisms (Martin 2003). Eighty-five percent of the province is forested (approximately $70000 \mathrm{~km}^{2}$ ), some $980 \mathrm{~km}^{2}$ of which is clear-cut annually (Martin 2003), fragmenting the forest and increasing forest edge. Fragmentation has been shown to have a negative effect on diverse species communities (Fahrig 2002, 2003). As of June 2013, 83 species in New
Brunswick were included on the "Species at Risk" list; approximately 45 rely on forest ecosystems for habitat (Species at Risk Act 2013). Harvesting can have a detrimental influence on biodiversity, particularly clear-cutting which alters microclimate, water yield and quality, soil properties, nutrient cycling, and species composition of both flora and fauna (Keenan and Kimmins 1993, Esseen and Renhorn 1998). An increase in fragmentation and forest edge may therefore reduce the numbers of interior forest species, especially those

\footnotetext{
${ }^{1}$ Department of Environmental Sciences, Dalhousie University, Halifax, NS B3H 4R2 Canada * corresponding author's e-mail: melanie.barry@dal.ca

${ }^{2}$ Department of Integrative Biology, University of Guelph, Guelph, ON N1G 2W1 Canada

${ }^{3}$ Department of Biology, Dalhousie University, Halifax, NS B3H 4R2 Canada
} 
sensitive to environmental changes. Lichens are a group of organisms that are sensitive to disturbance, particularly those in the genus Lobaria (Edman et al. 2008), which is common in mature, undisturbed deciduous- dominated forests of the Acadian Forest Region (Gowan and Brodo 1988, Cameron 2002, McMullin et al. 2008, McMullin et al. 2012). Species of Lobaria are sensitive to changes in light, temperature, and relative humidity (Gauslaa and Solhaug 1999).

Old-growth and mature forest habitats are rich with lichen species, including many that are not typically found in younger forests (Lesica et al. 1991, McMullin et. al. 2008). This is due to a greater number of available microhabitats created by an increase in structural complexity, and relative humidity is higher and more sustained as forests age (Stewart et al. 2003, McMullin et al. 2008, McMullin et al. 2010). Clearcutting, however, not only affects the area harvested but also fragments forests, and creating more edge habitats has been shown to cause changes in biodiversity (Rheault et al. 2002). There is an increase in sun and wind exposure which reduces humidity and moisture and creates greater temperature fluctuations (Rheault et al. 2002). There is a range of tolerance to changes in environmental conditions among lichen species which has allowed them to be useful bioindicators (Gauslaa and Solhaug 1999, Pipp et al. 2001, McMullin et al. 2008).

Several studies have examined the effects of clear-cuts and forest fragmentation on the biodiversity of the remaining adjacent forests (Renhorn et al. 1996, Esseen and Renhorn 1998, Moen and Jonsson 2003, Rheault et al. 2002). In Sweden, fragmentation was shown to decrease the population size of some lichen species because of changes in landscape and forest structure, particularly attributed to increasing forest edge (Moen and Jonsson 2003). Esseen and Renhorn (1998) illustrated that epiphytic lichens can be used as bioindicators of edge effects because they respond negatively to changes in their interior forest environment. In North America, however, little research has been done on the influence of edge effects on lichens, and in the Acadian Forest Region no published studies were found. In 2008, however, a study in northwestern New Brunswick assessed the effects of selective harvesting on Lobaria pulmonaria and L. quercizans. These species are common in New Brunswick's mature and undisturbed forests where they were found to be significantly more abundant than in disturbed forests (Gowan and Brodo 1988, Edman et al. 2008).

The aim of our study was to use locally abundant and sensitive lichens as bioindicators to better understand the effects of clear-cut harvesting on the biodiversity of remnant adjacent forests. Our specific objectives were: (1) to examine the three Lobaria species known to occur in the Acadian ForestL. pulmonaria (L.) Hoffm., L. quercizans Michx., and L. scrobiculata (Scop.) P. Gaertn.; (2) to calculate the distance that each species occurs from the forest edge; and, (3) to compare canopy closure and temperature at the forest edge and in the forest interior to correlate any differences with the presence of the species examined. Based on previous studies in other locations that assessed different sensitive lichen species, we expected there would be a reduced abundance of Lobaria due to the edge effect (Renhorn et al. 1996, Esseen and Renhorn 1998, Rheault et al. 2002). We also expected the interior of the forest to have more canopy closure and shade, lower and more sustained temperatures, and higher relative humidity than at the forest edge (Esseen and Renhorn 1998, Rheault et al. 2002, Gauslaa et al. 2009). Higher relative humidity is important for lichen growth because many species can absorb this moisture which is required for photosynthesis (Lange et al. 1986).

\section{Methods \\ Study Sites}

Twenty mature deciduous forest stands were selected in northeastern New Brunswick, each adjacent to a clear-cut ranging from 6-11 years-old (Fig. 1). Stands were located using maps derived from the resource inventory database of Fornebu Lumber Co of Bathurst, New Brunswick. The maps contained potential hardwood stands adjacent to 5-10 yearold clear cuts. Sample stands were ground truthed to ensure they were consistent with our maps and met the criteria for this study.

\section{Experimental Design}

At each study stand we started at the first accessible location where the edge of the forest met the adjacent clear cut. To determine the three transect locations at each site, a coin toss was used to randomly determine direction to go along the forest edge. A random number generator was used to determine the distance we walked to a maximum distance of $40 \mathrm{~m}$. The random number generator was used three times to determine the point that each of the three transects were established.

At the start and end of each transect the temperature $\left({ }^{\circ} \mathrm{C}\right)$ at the forest edge was recorded using a thermometer $(1.3 \mathrm{~m}$ above the ground) and canopy closure recorded using a spherical densiometer. Sampling began by walking into the forest while scanning all trees within $1.0 \mathrm{~m}$ of the transect for target lichens (L. pulmonaria, L. quercizans, and L. scrobiculata). Transects ended once one of the target species was identified. The distance from the lichen-bearing tree to the edge of the forest was measured with a 30- $\mathrm{m}$ measuring tape. Tree species were recorded as well as any of the three target lichen species present on the tree. Canopy closure and temperature were recorded adjacent to the lichen-bearing tree.

\section{Analyses}

Transects within stands could not be treated as independent points, as values for transects within stands tended to be extremely similar. Therefore, stands rather than transects were used as the unit of analysis, and the results refer to mean values across transects within stands. To test whether species varied in their distance to stand edges, we used an ANOVA with the presence of L. quercizans (present or not) and L. scrobiculata (present or not) and their interaction as fixed factors and distance to stand edge as the independent variable. This analysis did not include $L$. pulmonaria because $L$. pulmonaria was almost always present in all stands and absent from only one tree. Paired t-tests were used to compare cover and temperature between the edge and interior of the stands.

\section{Results}

We examined 20 sites and 60 transects. Ages of clear-cuts ranged from 6-11 years and averaged 9.2 years with a median age of 9.5 years. All three target lichens were located (Fig. 2). Average distance that all three species were found from the 


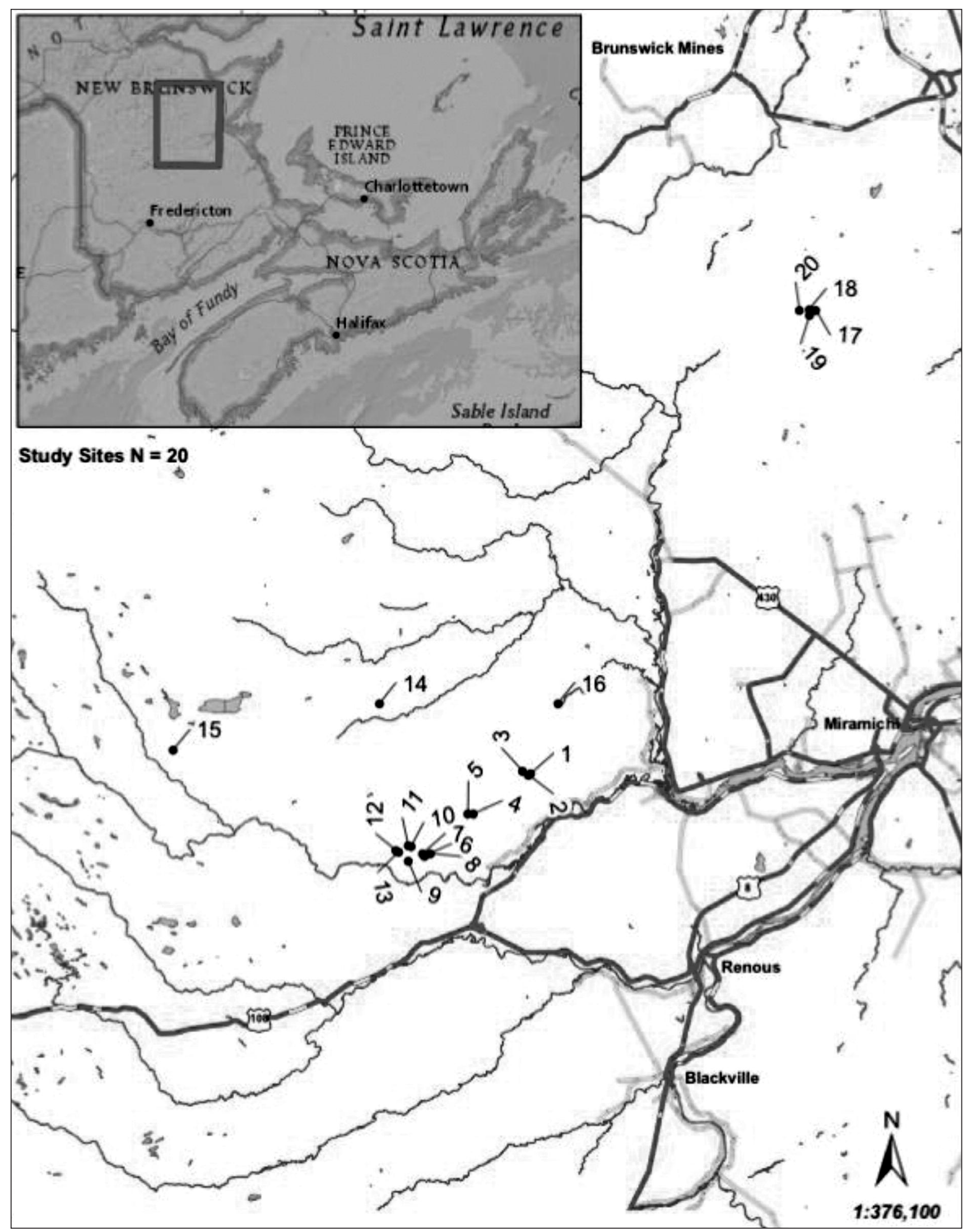

Fig. 1. Location of study site and transect lines in northeastern New Brunswick 

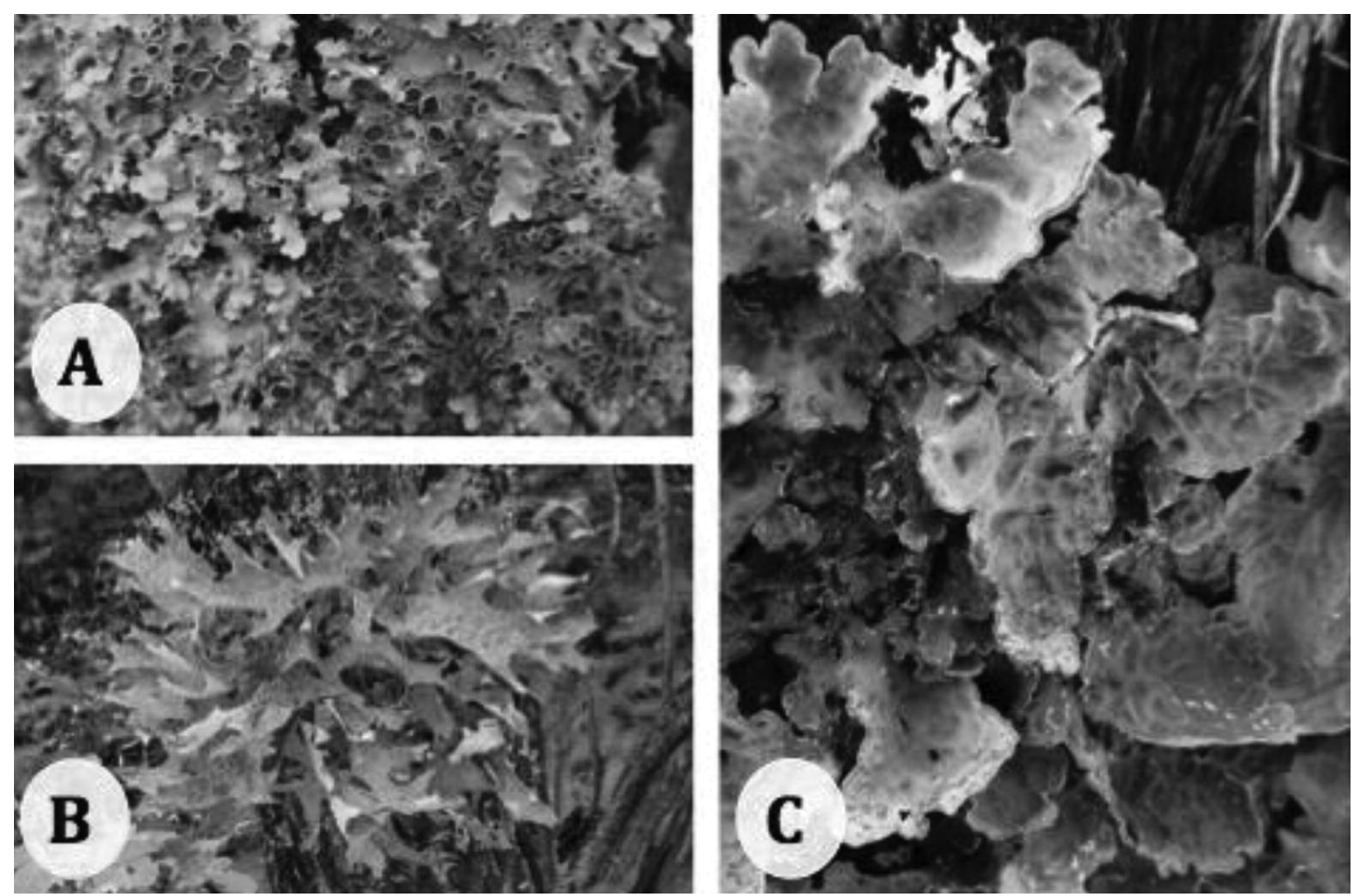

Fig. 2. Images of the three lichens examined: A) L. quercizans; B) L. pulmonaria; C) L. scrobiculata (photos by R.T. McMullin)

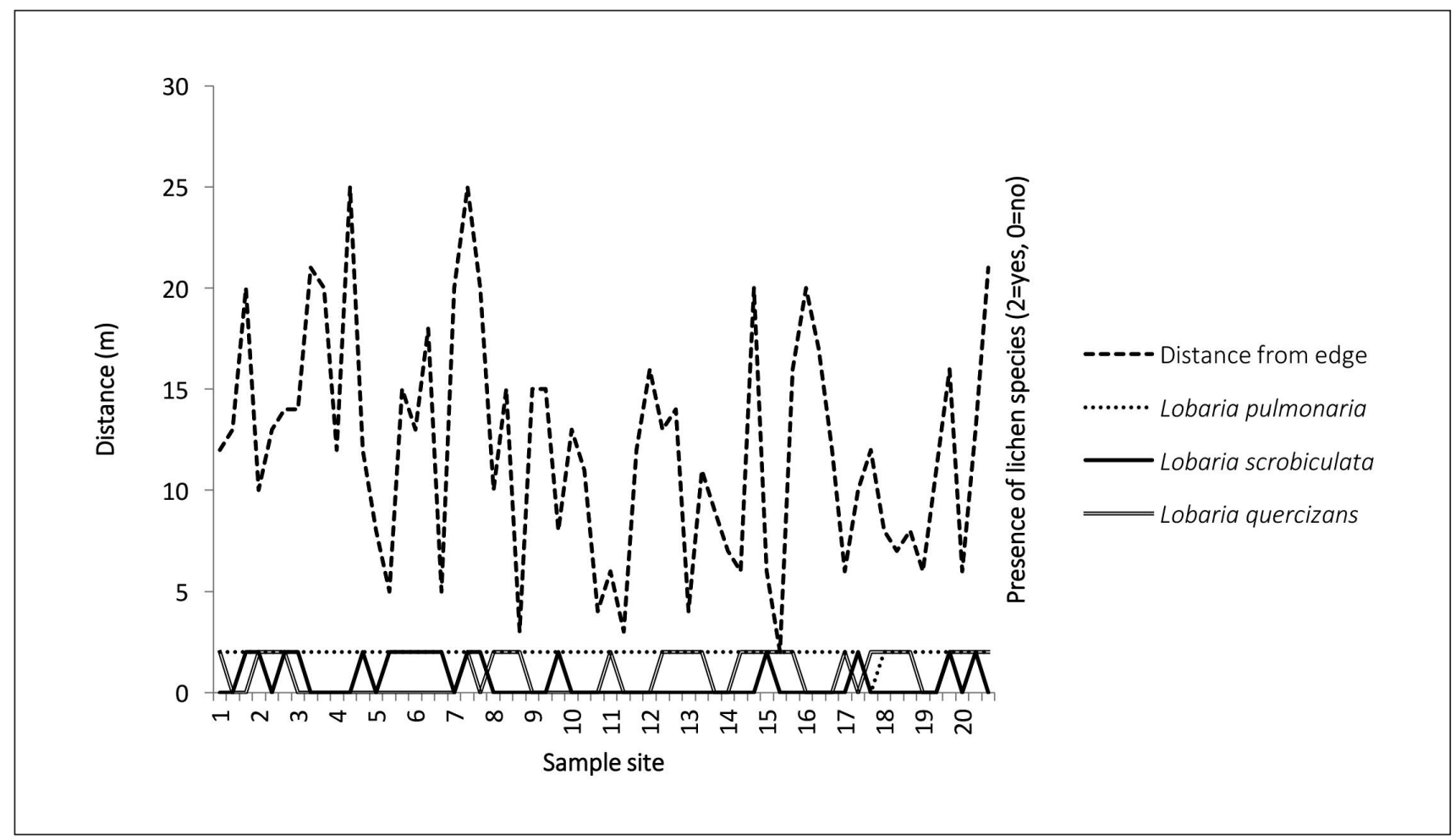

Fig. 3. Comparisons between distance that lichens were encountered from edge of the harvested area and the species that were present $(L$. pulmonaria, L. scobiculata and L. quercizansJ, where $2=$ present and $\mathrm{O}=$ absent 
edge was $12.12 \mathrm{~m}(+/-5.66 \mathrm{~m})$ with a median of $12 \mathrm{~m}$. Some lichens were found as close as $2 \mathrm{~m}$ from the edge and as far as $25 \mathrm{~m}$ (Fig. 3). L. pulmonaria occurred on 59 of the 60 trees sampled. Its average distance from the edge was $12.11 \mathrm{~m}$. Lobaria quercizans was found on 27 trees and was present on 13 of the $20(65 \%)$ study sites. Its average distance from the edge was $11.00 \mathrm{~m}$. Lobaria scrobiculata occurred on 17 of the 60 trees and present at 12 of the 20 (60\%) study sites (Fig. 3). Its mean distant from the edge was $13.18 \mathrm{~m}$ and it was not found beside any of the clear-cuts under nine years old (Fig. 3).

The average distance of trees did not vary significantly in relation to the presence of $L$. quercizans $\left(\mathrm{F}_{1,16}=1.11, \mathrm{P}=\right.$ $0.31)$; L. scrobiculata $\left(\mathrm{F}_{1,18}=1.24, \mathrm{P}=0.28\right)$; or their interaction $\left(\mathrm{F}_{1,6}=0.42, \mathrm{P}=0.53\right)$ (Fig. 4). Almost half the lichen-

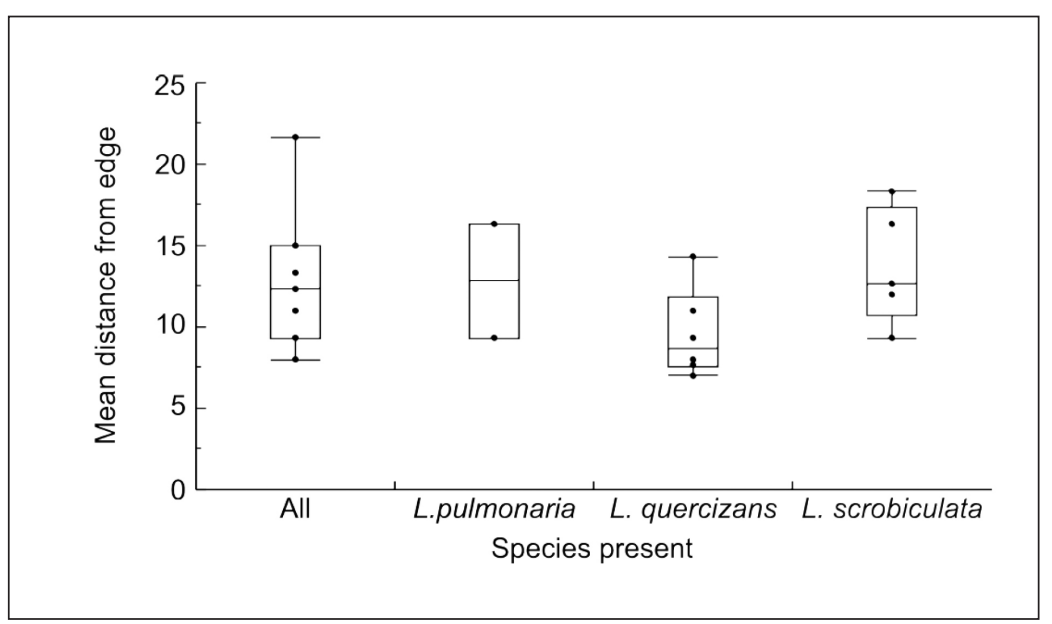

Fig. 4. Mean distance to stand edges from trees where each species of lichen was located. Lobaria pulmonaria occurred in all stands and on all but one tree; therefore, only the distances for the other two Lobaria species were compared statistically. The distance did not vary significantly between the presence of $L$. quercizans $\left(F_{1}{ }_{16}=\right.$ 1.11, $P=0.31)$, L. scrobiculata $\left(F_{1,18}=1.24, P=0.28\right)$ or their interaction $\left(F_{1,6}\right.$ $=0.42, P=0.53$ bearing trees sampled (28/60) were Acer saccharum Marshall (sugar maple). Acer rubrum L. (red maple) was the next most frequent (16/60). The rest of the species were Betula alleghaniensis Britt. (yellow birch), Fagus grandifolia Ehrh. (American beech), Fraxinus spp. (ash), and Populus tremuloides Michx. (trembling aspen), which were sampled seven, five, three and once respectively.

Canopy closure was measured at the forest edge and within the stand where one of three lichens was encountered (Fig. 5). Mean canopy closure at the edge was 6.9\% (+/- 10) with a median value of $1.7 \%$. Canopy closure was as low as $0.2 \%$ and as high as $42.8 \%$. Inside the mature forests mean canopy closure was $91.5 \%(+/-14.4)$ with a median value of $96.9 \%$. The lowest canopy closure was $23 \%$ and the maximum cover was $100 \%$. The mean percent cover $( \pm$ $\mathrm{SE})$ at the edge and centre of stands had a paired value of $\mathrm{t}_{19}=29.80, \mathrm{P}<0.0001$ (Fig. 6).

Mean temperatures were $1.5{ }^{\circ} \mathrm{C}$ lower inside the mature stand than at the edges. Some locations had virtually no change in temperatures while others differed by up to 5 ${ }^{\circ} \mathrm{C}$. The mean temperature $( \pm \mathrm{SE})$ at the edge and centre of stands for temperature varied with a paired value of $\mathrm{t}_{19}=3.87, \mathrm{P}=0.0010$ (Fig. 6). No correlation was found between age of the clearcut and the average distance from the edge.

\section{Discussion}

All three Lobaria species were affected by edge effects created by clear-cuts. This harvesting strategy creates edges along the remnant forests that have different environmental conditions than in the forest interior, which limits the colonization of Lobaria. The three species examined occurred on average 12.12 $\mathrm{m}$ from the edge of the harvest.

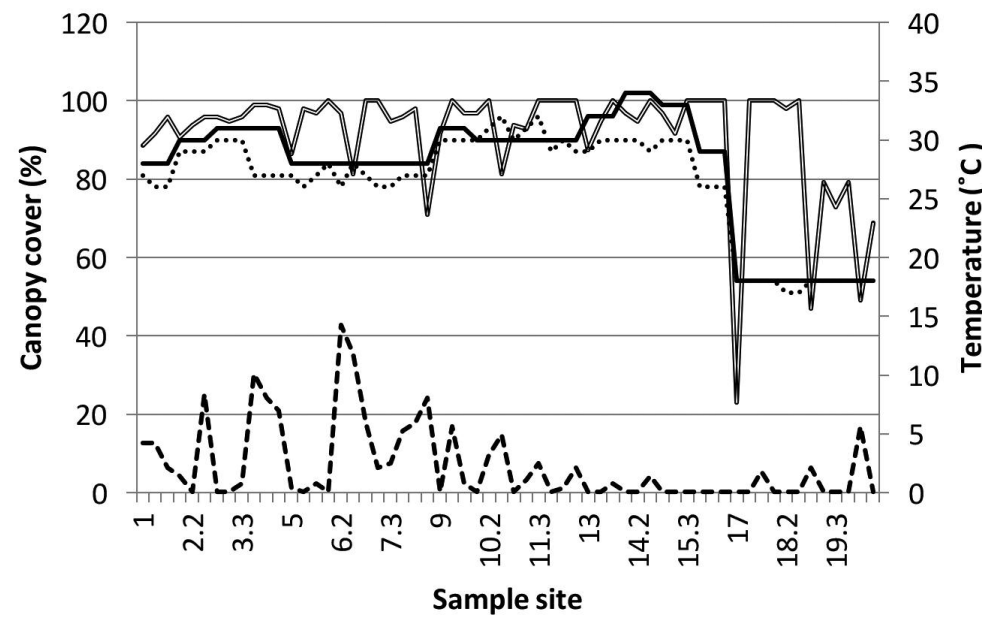

----- Canopy Cover at Edge \%

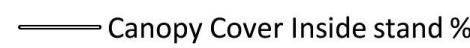

- Temperature at Edge

Temperature in Stand

Fig. 5. Mean comparisons between canopy closure and temperature at the edge of the clear-cut and interior portions of the remaining adjacent forests ( $n=20$ ) 


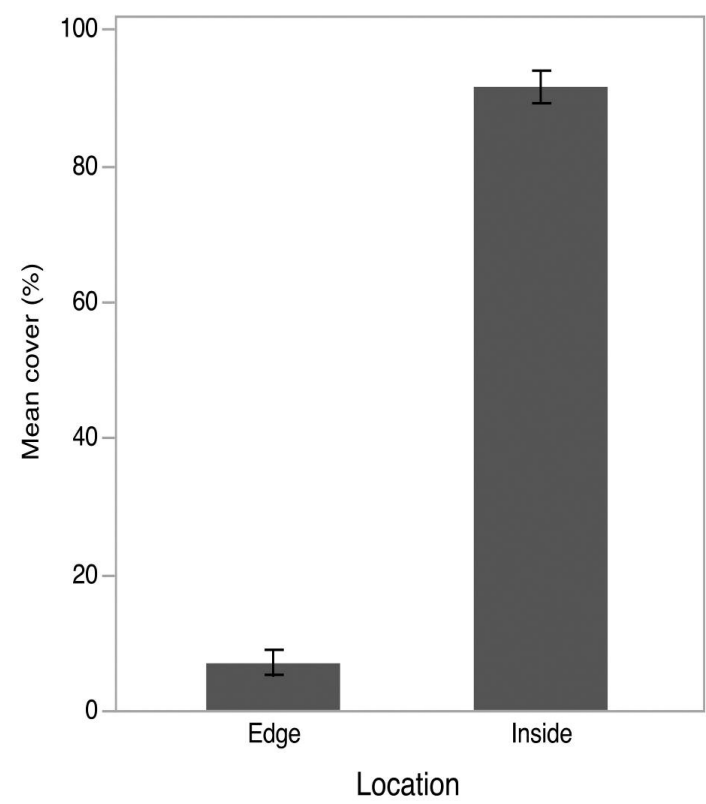

Fig. 6. Mean $( \pm S E)$ at the edge and centre of stands for mean percent canopy cover (paired $t_{19}=29.80, P<0.0001$ )

Lichens that are sensitive to disturbance are those that have narrow microhabitat requirements (Lesica et al. 1991, McMullin et al. 2013). Lobaria pulmonaria was the most tolerant to edge effects that we assessed. It was more frequently found closer to the edge than the other two species, which suggests it may be less sensitive to microclimatic changes created after clear-cutting. Lobaria scrobiculata was the most intolerant species of the three as it had the longest average distance from the edge.

The amount of available light and moisture are important for lichen colonization (Bartak et al. 2006, Gauslaa et al. 2009, McMullin et al. 2013). Higher moisture levels are typically preferred by foliose lichens (Gauslaa et al. 2009). We found a strong correlation between canopy closure and temperature at the edge and inside the stand. As we expected, temperatures at the forest edge were higher than in the interior, which is likely due to low canopy closure and increased exposure to the sun. Inside the forest, canopy closure was higher and temperatures were on average $1.47{ }^{\circ} \mathrm{C}$ lower. We also observed that the lichens assessed were typically growing on the side of the tree facing inward towards the forest where there was less direct contact with the sunlight. This finding suggests that Lobaria species prefer to avoid direct contact with sunlight, which further supports the reason for colonization being limited near the forest edge.

We did not assess lichen abundance but it did appear to be affected by edge effects. Lichens need moisture to photosynthesise and grow; therefore, canopy closure is beneficial because it limits sun exposure and desiccation, although too much canopy closure has also been shown to limit the growth of L. pulmonaria (Gauslaa et al. 2006, Nash 2008, Gauslaa et al. 2009). Atmospheric moisture can also help some lichens undergo photosynthesis without being exposed to liquid water (Lange et al. 1986). During our study a transition zone was observed where the abundance of the Lobaria species increased progressively the further away from the edge of the harvest, where humidity and canopy closure was higher. Edge effects have been studied using sensitive lichens by several researchers in different regions (Esseen and Renhorn 1998, Rheault et al. 2002, Edman et al. 2008). The main variables causing edge effects were relatively consistent among other studies: changes in temperature, sun exposure, wind exposure, and moisture (Esseen 1994, Sillet 1994, Lücking 1997, McMullin et al. 2010). Esseen and Renhorn (1998) found similar results to ours in northwestern Sweden using the lichen Alectoria sarmentosa (Ach.) Ach. They calculated that it had a mean distance from the edge of $10.11 \mathrm{~m}$, which is similar to our result of $12.12 \mathrm{~m}$. However, results can be wide ranging; for example, another study conducted on A. sarmentosa showed that edge effects can extend as far as $58 \mathrm{~m}$ (Esseen 2006). Depending on location and topography, microclimate changes within newly created forest edges may not be severe enough to physically impact some epiphytic lichens (Renhorn et al. 1996). Therefore, any assessment of edge effects should use sensitive lichens that are regionally common.

\section{Conclusion}

All three species of the genus Lobaria are affected by newly created forest edges after clear-cut harvesting in the Acadian Forest. A decrease in moisture and an increase in light and temperature appear to be the primary causes of the edge effect. The mean influence of edge effects on the species is $12.12 \mathrm{~m}$. Therefore, the area required for residual blocks of trees or legacy clumps to contain some interior forest conditions after harvesting needs to be over $24 \mathrm{~m}$ in diameter, but for there to be enough interior forest to provide the conditions to support sensitive species such as Lobaria spp., a substantially greater area is required. Further research is needed to understand more precisely how much area is required. Forest managers can use these findings to better understand the impacts of clear-cutting, which can contribute to the development of more sustainable silvicultural practices that include the conservation of biodiversity.

\section{References}

Bartak, M., K.A. Solhaug, H. Vrablikova and Y. Gauslaa. 2006. Curling during desiccationprotects the foliose lichen Lobaria pulmonaria against photoinhibition. Oecologia 149(4): 553560.

Cameron, R.P. 2002. Habitat features associated with epiphytic lichens in managed and unmanaged forests in Nova Scotia. Northeast Nat. 9: 27-46.

Edman, M., A.-M. Eriksson and M.-A. Villard. 2008. Effects of selection cutting on the abundance and fertility of indicator lichens Lobaria pulmonaria and Lobaria quercizans. J. Appl. Ecol. 45(1): 26-33.

Esseen, P.-A. 1994. Tree mortality patterns after experimental fragmentation of an old-growth conifer forest. Conserv. Biol. 68: 19-28. Esseen, P.-A. 2006. Edge influence on the old-growth forest indicator lichen Alectoia sarmentosa in natural ecotones. J. Veg. Sci. 17(2): 185-194

Esseen, P.-A. and K.-E. Renhorn. 1998. Edge effects on an epiphytic lichen in fragmented forests. Conserv. Biol. 12(6): 1307-1317.

Fahrig, L. 2002. Effect of habitat fragmentation on the extinction threshold: A synthesis. Ecol. Appl. 12(2): 346-353. 
Fahrig, L. 2003. Effects of habitat fragmentation on biodiversity. Annu. Rev. Ecol. Evol. S. 34: 487-515.

Gauslaa, Y. and K. Solhaug. 1999. High-light damage in air-dry thalli of the old forest lichen Lobaria pulmonaria - interactions of irradiance, exposure duration and high temperature. J. Exper. Bot. 50(334): 697-705.

Gauslaa, Y., M. Lie, K.A. Solhaug and M. Ohlson. 2006. Growth and ecophysiological acclimation of the foliose lichen Lobaria pulmonaria in forests with contrasting light climates. Oecologia 147: 406-416.

Gauslaa, Y., K. Palmqvis, K.A. Solhaug, O. Hilmo, H. Holien, L. Nybakken and M. Ohlson. 2009. Size-dependent growth of two old-growth associated macrolichen species. New Phytol. 181(3): 683-692.

Gowan, S.P. and I.M. Brodo. 1988. The lichens of Fundy National Park, New Brunswick, Canada. The Bryologist 91: 255-325.

Keenan, R. J. and J. Kimmins. 1993. The ecological effects of clearcutting. Environ. Revol. 1: 121-144.

Lange, O. L., E. Kilian and H. Ziegler. 1986. Water vapor uptake and photosynthesis of lichens: performance differences in species with green and blue-green algae as phycobionts. Oecologia 71(1): 104-110.

Lesica, P., B. McCune, S. V. Cooper, and W. S. Hong. 1991. Differences in lichen and bryophyte communities between old-growth and managed second-growth forests in the Swan Valley, Montana. Can. J. Bot. 69: 1745-1755.

Lücking, R. 1997. The use of foliicolous lichens as bioindicators in the tropics, with special reference to the microclimate. Abstracta Botanica, 21(1), 99-116.

Martin, G. 2003. Management of New Brunswick's Crown Forest. Depart. Natural Resources. 24 p.

McMullin, R. T., I.D. Thompson and S.G. Newmaster. 2013. Lichen conservation in heavily managed boreal forests. Conserv. Biol. 27: 1020-1030.
McMullin, R.T., S.R. Clayden, S.B. Selva, R. Curley and L.J. Schram. 2012. The first lichen checklist for Prince Edward Island, Canada. Evansia 29: 4-25.

McMullin, R. T., P.N. Duinker, R.P. Cameron, D.H. Richardson and I.M. Brodo. 2008. Lichens of coniferous old-growth forests of southwestern Nova Scotia, Canada: Diversity and present status. The Bryologist 111(4): 620-637.

McMullin, R.T., P.N. Duinker, D.H.S. Richardson, R.P. Cameron, D.C. Hamilton and S.G. Newmaster. 2010. Relationships between the structural complexity and lichen community in coniferous forests of southwestern Nova Scotia. For. Ecol. Manag. 260: 744-749. Nash, T.H. 2008. Lichen Biology $2^{\text {nd }}$ Edition. Cambridge University Press, New York, USA. 486 p.

Moen, J. and B.G. Jonsson. 2003. Edge effects on liverworts and lichens in forest patches in a mosaic of boreal forest and wetland. Conserv. Biol. 17(2): 380-388.

Pipp, A.K., C. Henderson and R.M. Callaway. 2001. Effects of forest age and forest structure on epiphytic lichen biomass and diversity in a Douglas-fir forest. Northwest Sci. 75: 12-24.

Renhorn, K.-E., P.-A. Esseen, K. Palmqvist and B. Sundberg. 1996. Growth and vitality of epiphytic lichens. Oecologia 109(1): $1-9$.

Rheault, H., P. Drapeau, Y. Bergeron and P.-A. Esseen. 2002. Edge effects on epiphytic lichens in managed black spruce forests of eastern North America. Can. J. For. Res. 33: 23-32.

Sillet, S. 1994. Growth rates of two epiphytic cyanolichen species at the edge and in the interior of a 700-year-old Douglas-fir forest in the Western Cascades of Oregon. The Bryologist 97: 361-374.

Species at Risk Act. 2013. New Brunswick Regulation 2013-38: Under the Species at Risk Act (O.C. 2013-143) Available from http://www.gnb.ca/0062/acts/BBR-2013/2013-38.pdf

Stewart, B.J., P.D. Neily, E.J. Quigley, A.P. Duke and L.K. Benjamin. 2003. Selected Nova Scotia old-growth forests: Age, ecology, structure, scoring. Forest. Chron. 79: 632-644. 